\title{
REKONSTRUKSI HUKUM ISLAM \\ (Telaah Pemikiran Fiqih Indonesia)
}

\author{
Oleh : Abd Rasyid Gandon
}

\begin{abstract}
ABSTRAK
Indonesia dengan setting objektif yang bukan negara agama pluralik selalu berhadapan sebuah kebutuhan adanya rekonstruksi Hukum Islam, yakni mencerdasi eksistensi hukum Islam agar senantiasa fungsional.

Dalam rentang yang cukup lama hukum Islam di Indonesia dibingkai oleh pemahaman dan keyakinan dari umat Islam yang menempatkan rumusan fiqih ulama-ulama terdahulu, terutama Imam Mazhab empat scbagai rumusan yang bersilat mutlak untuk diikuti dan tidak perlu digugat, karena itu rumusan ini jadi sebuah teologi Umat Islam.

Akan tetapi dengan munculnya ulama-ulama mujaddid seperti Muhammad Bin Abdul wahab, Ibnu Taimiyah, Muhamad lqbal, KH. Ahmad Dahlan Hukum Islam (Baca perumusan fiqih) menjadi dinamis, is selalu di rekonstruksi hingga sampai kepada taraf suatu kebutuhan.

"Tulisan inimendeskripsikan kondisi Objektif Indonesia yang mutlak mernerlukan upaya rekonstruksi hukum

Islam.

Kata Kunci : Rekonstruksi Hukum Islam, Indonesia Dan Pemikiran Fiqih.
\end{abstract}




\section{PENDAHULUAN}

Indonesia bukan negara agama, namun bukan pula negara yang mengbaikan pengembangan hukum agama, hal ini karena masyarakatnya yang dominan beragama Islam. dalam nuansa masyarakat yang religius. Karena dominasi penganut agama 'slam. maka aspek fikhi mutlak meliputi keberagamaan umat Islam Indonesia disamping aspek teologi. Apek teologi merupakan unsur pokok agama yang memberikan nuansa pengalaman batin, sedang aspek fikhi merupakan kebutuhan umat Islam dalam tata sosialnya. Sebab itu pandangan seorang muslim terhadap kedua aspek ini hares bersi fat integratil dan karena itu pula Islam adalah agama yang berdiri diatas dua komponen dalam bentuk komplementer yakni akidah (teologi) dan svariah (fikhi). Kedua komponen ini diperindah dan disempurnakan oleh akhlak (etika).

Berkaitan dengan salah sate komponen tersebut diatas. maka pembahasan tulisan ini mencoba memfokuskan kepada komponen pemikiran tkhi dengan metode pendekatan Sosiogis Historis Diskriptif. Oleh karena itu isu sentral yang akan dikembangkan adalah bagaimana posisi fikhi dalam kancah pertumbuhan dan perkembangan pemikiran dan sejauh mana pengaruhnya terhadap pemikiran fikhi di Indonesia. Dengan demikian topik "Rekonstruksi Hukum Islam beralasan untuk di Introduksi."

\section{KEBANGKITAN ISLAM}

Setelah fase stagnasi iitihad perkembangan baru yang muncul adalah masa kebangkitan Islam. Masa ini mempunyai dua bentuk, yaitu gerakan pemumian dianggap awal kebangkitan pembaharuan pemikiran dalam Islam.'

Sedangkan kebangkitan Islam dalam bentuk gerakan pemurnian Islam dianggap abad XVII M. dengan munculnva Muhammad bin Abdul Wahhab (1703-1787 M) dengan ajaran wahabi yang sebelumnya telah muncul tokoh terkenal yaitu Ibnu Taimiyah (1263-1328 NI) dan Ibnu Qayyim (1292-1356 $\mathrm{M}){ }^{2}$ 
Adapun gerakan pembaharuan pemikiran dihidang fikhi, umumnya penulis hukum Islam berpendapat bahwa sejak abad XIX M. hukum Islam memasuki tahap baru dalam perkembangannya, yakni tahap kebangkitan setelah mengalami kemunduran ratusan tahun. ${ }^{3}$ Kebangkitan ini oleh sebagian penulis hukum Islam disebut sebagai Ease neo ijtihad atau free will dalam perkembangannya hukum

Kebangkitan ini menghilangkan pengaruh taklid, yang pada abad XVIII dan XIX M. telah mencapai titik klimaksnya dengan menolak segala hal yang baru khusunya yang datang dari Barat.

Taklid yang dinilai sebagai fenomena pertumbuhandan perkembangan pemikiran fikhi yang tidak proporsional. Seorang muqallid mengikuti pendapat madzhab tertentu tanpa mengetahui sedikitpun dasar pendapat yang dianutnya, dan juga tidak mau taint apakah pendapat itu relevan dengan zaman atau tidak. Hal yang demikian pernah menjadi realita keberagamaan muslim Indonesia, terutama di masa kolonial. Sehingga boleh jadi penilaian Snouck Hurgronye tidak sepenuhnya salah, bahwa orang Indonesia lebih memperhatikan persoalan Islam sebagai agama dalam pengertian yang sempit ketimbang memperhatikan aspek politik maupun aspek sosial dari agama Islam, bahkan bersama Van Den Berg, is mengemukakan laporan bahwa banyak orang Islam di Jawa hanya Islam namanya saja.

Iqba1 $^{7},(1873-1938)$ sebagai penggagas rekonstruksi pemikiran hukum Islam, tidak lahir begitu raja, melainkan dilatarbelakangi oleh prosesi yang pasti bahwa sasaran ide perlunya pembangunan kembali alarm pemikiran Islam antara lain memunculkan kembali substansi pemikiran fikhi sebagaimana yang ditunjukkan oleh sejarah kecemerlangan pemikiran hukum fikhi. Efektifitas hukum fikhi dikala itu terletak pada kemampuan hukum fikhi itu sendiri memenuhi umat Islam menurut kondisinya. Akibatnya, tidak jarang dijumpai Imam mazhab memberikan dua kesimpulan fatwa terhadap satu masalah dikarenakan adanya perbedaan lingkungan dan budaya seperti Imam Syafi'i yang mempunyai qaul qadim dan qaul 
Motif rekonstruksi pemikiran fikhi yang dikemukakan lqbal, demikian juga sumber-sumber lain, disebabkan kesalahkaprahan pemikiran fikhi sejak isu tertutupnya pintu ijtihad pertengahan abad IV H. sehingga dengan isu ini, potensi dinamika hukum fikhi menjadi terkubur, fikhi tidak lagi sebagai pemikiran yang aktual, melainkan sebagai doktrin agama yang bersifat absolut dan sakral, sehingga nilai otoritatif suatu pendapat ditentukan kepada tokoh madzhab tertentu, bukan pada dalil serta argumen yang menjadi landasannya.

Dengan demikian taklid merupakan biang kesalahkaprahan yang perlu diluruskan, stagnasi ijtihad yang melahirkan kristalisasi pemikiran, semakin menjauhkan dinamika hukum fikhi dari rotasinya berupa munculnya madzabisme serta eksklusivisme dikalangan umatIslam. Fakta kesalahkaprahan ini diperlukan adanya upaya merekonstruksi pemikiran fikhi sehagaimana diawal bangkitnya madzhab-madzhab yang dulunya penuh dinamika. Sehingga pada dewasa ini sudah seharusnya kita tidak begitu saja hersikap membiarkan sistem hukum Islam tanpa pemikiran yang mendalam, dan harus berani membangun kembali pemikiran Islam.

Desantilana, seorang ahli hukum bangsa Italia menyebutkan bahwa motivasi orang Barat mempelajari hukum Islam, karena merupakan sumber yang pasti bagi prinsip-prinsip hukum Eropa modern. Karena itu menurutnya hukum Islam telah meminjamkan kepada masyarakat Barat kaidah-kaidah hukum teknis dan dun-fa perdagangan dan perseroan terbatas misalnya, perkatan cheque yang berasal dari perbendaharaan hukum Islam yaitu shakk yang berarti dokumen tertulis.

\section{BIDANG PEMBARIIAN PEMIKIRAN}

Hampir semua ahli sejarah bahwa kebangkitan kembali kaum muslimin baru dimulai awal abad XIX yang dimotori olch Mesir, Turki dan India)' Pengaruh kebangkitan ini meliputi berbagai bidang seperti ekonomi, politik dan sosial disamping munculnya perundang-undangan yang haru, maka wajar jika kaum muslimin mencoha kembali merekonstruksi pemikiran fikhi guna memenuhi tuntutan hukum haru. 
Madzhab ikhtiri inilah dianggap sebagai model pendekatan bermadzhab di Indonesia yang berarti sebagai pemikiran fikhi, sebab pada masa-masa sebelum kemerdekaan, kecenderungan kepada mazhab tertentu, dan kecenderungan menolak pembaharuan bahkan pemurnian agama adalah fakta sejarah yang tidak bisa dipungkiri.

Sejarah telah mencatat bahwa pendeklarasian Nadhlatul Lllama 1926, adalah sebagai salah satu upaya untuk merespon pembaharuan, dan menekan keterkaitan ajarannya dengan salah saw mazhah tertentu (Syall'i)." Hal mana hukum fikhi Syafi'l lebih dekat dengan kepribadian bangsa Indonesia yang lehih menonjolkan sikap kebersamaan."

Perkembangan berikutnya dalam kerangka pemikiran fikhi sudah mulai terbuka, fikhi Syatii yang tidak sesuai mengikuti keadaan yang berkembang. Dizaman modem ini kctatnva iiah kahul yang diletakkan oleh al Syarri dalam menyerahkan sesuatu cukup dengan isyarat itu sudah dianggap cukup, dan klta tidak merasa sah."

ljtihad sebagai isu central rekon struksi dan raktualisasi hukum fikhi tentu tidak dilakukan oleh semua orang keetiall bagi mereka yang memiliki kualifikasi yang memadai. Karena itu dizaman kebangkitan hukum Islam perlu rekonstruks1 pemikiran tentang kualirikast Otilvad, dalam kerangka membangun waeana pemikiran hukum fikhi sesuai tuntutan perkembangan ilmu pengetahuan dewasa

Perbedaan antara ilmu agama dengan non agama dalam konteks kekinian sudah sangat transparan sehingga suht dibayangkan seseorang dapat menguasal seluruh ilmu keterbatasan memberi kepastian hukum peristivvaperistiwa haru yang begitu banyak bennuneulan. Oleh sebab itu fikhi eksklusivisme sebagai pengehirian dinamika madzhab fikhi memang perlu direkonstruksi sehingga jati din madzhab diraih kembali. 


\section{KESIMPULAN}

1. Taklid eksklusivisme dan sektarianisme adalah simbol kristalisasi pemikiran yang menggerogoti dinamika fikhi. ketiganya adalah penghambat Naktualisasi hukum $\mathrm{t}$ khi sehingga perlu upaya konscptual berupa rekonstalks' alam pikiran Islam sebagaimana yang diwariskan oleh mujtahid dunasa lalu. keterbukaan Ivawasan dan kejemihan doktrin agama dapat menjembatani konsep agama Islam dengan pranata sosial modern yang penuh kompleksitas.

2. Sejak pasca kemerdekaan perkembanv.an pemikiran hukum Islam (likhi) di tanah air makin menampakkan intensitasnya yang cukup tinggi, beberapa karya monumental ulama Indonesia telah menampung reformulasi hukum fikhi sesuai dengan kondisi kekinian dun alam Indonesia.

3. Hukum Islam (fikhi) yang terkoleksi dalam hteratur balk klasik maupun modern hendaknya dipandang sebagai solusi masalah fikhi sesuai dengan tempat dan perkembangan zaman. Fikhi adalah kebutuhan masyarakat, senap kurun waktu memungkinkan adanya retormulasi baik itu yang bersi fat administratif. tambahan maupun remterpretasi. 


\section{CATATAN KAKI:}

1. Harun Nasution. Alain Rosintil Gagasan don Pentikiran, (Bandung: Mizan, 1995), h. 145.

2. Munawir Sadzali, Islam Realitas Baru don Orientasi Masa Depan, (Jakarta: LT Press. 1993). h. 5S. Lihat Harun Nasution, Pcmhahruon Dolan! Islam. Sejarah P,",:k/ron don (ThroAan, (Jakarta: Milan BIM:111g. 1992 ). h. 23.

3. Muhammad al-Bahi, Al Fikrul Islam Wa Shirotuhu Bil itimnanl Gharibiyyi, (Ted.). (Jakarta: Pustaka Panjimas, 1986), h. 88.

4. Sudirman Tobba, Pembaharuan Hukum Islam, (Jakarta: LSAF, 1989), h. 145 .

5. Nucholis Madjid, Islam Ke Merdekaan dan Ke Indonesiaan, (Bandung: Mizan, 1989), h. 311.

6. Deliar Noer, Gerakan Modern Islam dt Indonesia 1900 - 1942, (Jakarta: LP3ES. 1991), Ii.

7. Dialah tokoh yang secara rekeonstruksi pemikiran dalam Islam dengan menyusun sebuah buku berjudul, The Reconstruction Of Religius Thought In Islam, dalam buku itu Iqbal membantu umat Islam Menemukan jati dirinya (sikap) ditengah keragaman dan kebingungan yang ditimbulkan oleh pemikiran Modern, lihat Muhammad Iqbal, The Reconstruction Of Religius Thought In Islam. (New Delhi: Kitab Bhavan, 1981), h. 163.

8. Faruq Abu Zaid, Mujahiddin. (Mesir: Darul Mawafiq, t.th), h. 32, Lihat Haru Nasution (Islam Rasiuonal ....), Op cit, h. 401.

9. Faruq Abu Zaid, Op. cit., 11, 49.

10. Joseph Schaiht, Islamic Relights Law. dalam, The LegacivOif Islam, (Oxford University Press, 1994), h. 401.

11. Faruq Abu Zaid, Op. en. h. 56, Harun Nasution (Islam Rasional), $O p$. cit. h. 152 ,

12. Mohammad Daud Ali, 1-/ukum Islam Pengantar Ihnu Hukum dal, Tata Negara, (Jakarta: Grafindo Persada, 1993, h. 181. 
13. Rahmat Djatmiko, Sosiologi Hukum Ham Indonesia Dahill! Kontrovensi Pemikinin Islam di Indonesia, (Bandung: Reim) Rosda Karya, 1991), h. 229.

14. Deliar Noer, Op. cit., 224.

15. Ibid. h.229-230

Jurnal Al-Syir'ah Vol. 1 No. 2 Juli-Desember 2003 